\title{
The Role of Values and Attitudes in Political Participation
}

\author{
Suhana $\operatorname{Saad}^{1} \&$ Ali Salman ${ }^{2}$ \\ ${ }^{1}$ School of Social, Development \& Environmental Studies, Faculty of Social Sciences \& Humanities, Universiti \\ Kebangsaan Malaysia, Bangi, Malaysia \\ ${ }^{2}$ School of Media \& Communication Studies, Faculty of Social Sciences \& Humanities, Universiti Kebangsaan \\ Malaysia, Bangi, Malaysia \\ Correspondence: Suhana Saad, School of Social, Development \& Environmental Studies, Faculty of Social \\ Sciences \& Humanities, Universiti Kebangsaan Malaysia, Bangi, Selangor, Malaysia. E-mail: \\ suhanasaad@ymail.com
}

Received: February 12, 2013 Accepted: March 29, 2013 Online Published: April 25, 2013

doi:10.5539/ass.v9n8p9 URL: http://dx.doi.org/10.5539/ass.v9n8p9

This project is funded by the Fundamental Research Grant Scheme (Universiti Kebangsaan Malaysia) under the research code: FRGS/1/2011/SS/UKM/02/21

\begin{abstract}
This research focuses on political culture with a special reference to political participation of the Malays and the non-Malays in district of Hulu Langat, Malaysia. Political landscape in Malaysia is normally being observed in term of ethnicity. This is why political observers in Malaysia claim that the goal of development and individual's behavior towards politics are habitually govern by ethnicity. Therefore, this paper aims to scrutinize the significance of value and attitude in political participation between Malay and non-Malay. These two vital factors are constanly being neglected in observing political participation. Value and attitude are also positively involved with conventional and non-conventional political participation, while socio-economic status only acts as an underpinning principle. The research was held in Hulu Langat District in Malaysia and rationally being chosen due to its ethnic composition is similar to Malaysian's ethnic composition, namely Bumiputera, Chinese and Indian. Data was collected through qualitative method that emphasized political participation and respondents' perspectives on politics and leadership. A total of 400 respondents were sampled involving 208 Malays, 148 Chinese and 44 Indians. The pattern of political participation in this area can explain the politics scenario or political culture among multi-ethnic society in Malaysia.
\end{abstract}

Keywords: political participation, value and attitude, political efficacy, cynical political attitudes, political trust

\section{Introduction}

In Malaysia, political objectives, development goals, education and economic policy, aven attitude is dependent on ethnicity factor (Indorf, 1979). According to Handelman (2000) the Malays have dominated the political system and bureaucracy, while the Chinese dominate the private sector. However, the reviewer believes ethnicity bias may only be acceptable in the context of institutions only, such as the dominance of the political party, election, economic, educational and public administration. The dominance of institutions is an effective way to guard the ethnic conflict. But more importantly, the dominance and ethnicity bias exists due to the institution as a mechanism for controlling the interest of the ruling party and political power (Esman, 1973). Political control such as this has in fact created a large gap in political participation between Malays and non Malays in Malaysia.

However, if Malaysian politics is seen in its micro form, which is outside the influence and control of institution, the question arising will be are there other factors that could explain the phenomenon of political culture in Malaysia? This question is worth examining because until now ethnicity is considered a key factor in politics in Malaysia. The researchers assume that there are other factors that could explain the political scenario in Malaysia, namely the question of political culture. This assumption is based on the view by Almond (1990) that social role and experience is often overlooked in research related to political participation, whereas this factor is so important. 
Milbrath and Goel (1977) claim that values and attitudes have a positive relationship with both conventional and unconventional political participation. Socio-economic status is only the basic principle of political participation (Mishler \& Clarke, 1995).

This paper examines the importance of values and attitudes in understanding the political culture, especially political participation, between the Malays and non Malays. The study involved 400 respondents who were selected using purposive sampling method and the location of the study is Hulu Langat, one of the areas with multi-ethnic population. The rational of choosing Hulu Langat is that its ethnic composition is representative of Malaysia's population. For example, the ethnic composition of Malaysia is 65.9 per cent Bumiputera, Chinese 25.2 per cent and India 7.5 percent. The ethnic composition of Hulu Langat is as follows: 52 percent Malays, 37 percent Chinese and 11 percent Indians. Based on the ethnic composition of the community here, it can be defined as multi-ethnic. Thus, the patterns of political participation here could explain the patterns of political participation / political culture of multi-ethnic society in Malaysia.

\section{The Concept of Political Participation}

Political participation is defined as any form or activities that impact on decisions. In most liberal democratic countries, political participation is to influence the outcome of a policy. In countries that have a non-democratic system, participation generally means accepting the final decision from the government. Political activity refers to the given votes, support or withdrawing oneself from the support.

In countries that practice authoritarian system, most of the people are receivers and in a totalitarian system the people are the participants (on the output side) (Isaak, 1987). According to Conge (1988), participation can be by an individual or a group, local or national, oral or written and by force or not. Participation is a manifestation of support. It is based on the needs and expectations of the people to show their role as strugglers of interest, legitimacy strugglers, voter, in certain circumstances as policy makers or protesters (the opposition) (Martin, 1992).

Wasburn (1982) discusses political participation by dividing it into two aspects. The first is a behavioral routine (routine act) that is political participation which is encouraged such as being a member of an organization that champions the welfare of students and this participation does not violate the power, authority and social system.

Apart from that, voting also has been categorized as a routine political participation. In contrast, a non-routine participation is a political act or behaviour which is not encouraged or which violates the social system. It is based on feelings of dissatisfaction about something like a political and socio-economic, policy and activities of politicians. All this can encourage a non routine participation such as involving in a social movements to demand for changes relating to social order.

\section{Level of Political Participation}

According to Isaac (1987) and Rodee et. al (1983), one measure of the level of political participation is the number that come out to vote. In this case Rodee et. al (1983) has identified the level of political participation based on the number of voter turnout as shown in Table 1.

Table 1. Level of political participation based on percentage of exit polling (come out to vote?)

\begin{tabular}{cc}
\hline Percentage & Level \\
\hline $85-95$ & Very High \\
$70-85$ & High \\
$65-70$ & Average \\
$55-65$ & Low \\
\hline
\end{tabular}

Source: Rodee et. al (1983).

Based on the percentage and the level used by Rodee et. al (1983), the number who came out to vote for the Hulu Langat is shown in Table 2. 
Table 2. Level of political participation based on number of exit polling (those who come out to vote)

\begin{tabular}{ccccc}
\hline Parliment & Year & Number of Voters & Percentage of Voters & Level \\
\hline \multirow{3}{*}{ Hulu Langat } & 1990 & 64,264 & 76.59 & High \\
& 1995 & 66,747 & 71.60 & High \\
& 1999 & 70,819 & 75.63 & high \\
& 2004 & 79,999 & 75.97 & High \\
\hline
\end{tabular}

Source: General Election Report for 1990, 1995, 1999 and Utusan Malaysia 23 Mac 2004.

The number of voter turnout for 1990, 1995, 1999 and 2004 General Elections are high. There are several factors that can be associated with a high percentage of the number of voter turnout, particularly in terms of urban population, which is high at 97 percent as compared to rural areas, which is only 3 percent. Large urban population showed a good level of urbanization in this area. It also provides good access for people to vote.

Increased level of urbanization is accompanied by a high literacy level. Many people are literate and have the opportunity in education, and awareness of responsibility as citizens in a democratic country has also increased.

Political participation may consist of several stages such as indirectly involve, just voting, involved in the collective activity, campaigning for the party and fully engaged (Verb \& Nie, 1972). Hierarchy of political participation in some form as shown in Figure 1.

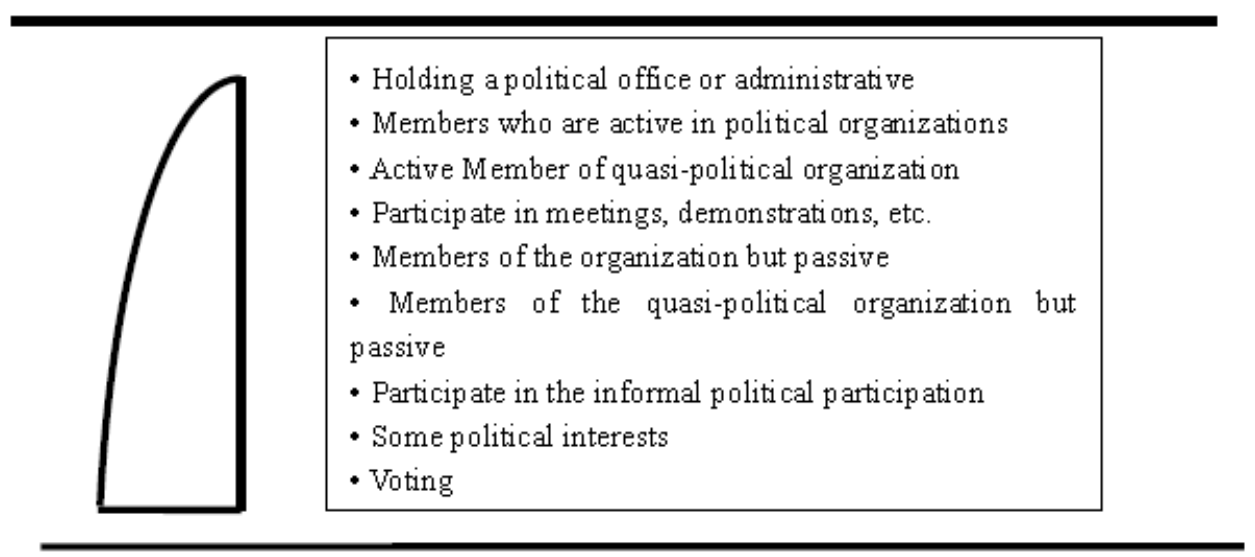

Figure 1.

Source: Rush (1992:112)

\section{Values and Attitude in Political Participation}

Value is defined as a parameter for what is right and wrong, acceptable and not acceptable in politics, including a policy such as freedom, safety, welfare or participation process, compromise and agreement. Value is also the results from other components of political culture such as values and attitudes towards politics and political behavior (Deutch, 1974). Values and attitude factors involves three key concepts of Political efficacy, cynical political attitudes and political trust.

As discussed previously, political efficacy is the optimistic view of someone who believes that he can make a difference, whereas cynical political attitudes is rather pessimistic assumption by and an individual politics and also leaders. The concept of political trust on the other hand is the belief of an individual towards politics and also a leader who can make a difference and bring about change.

\subsection{Political Efficacy}

Between participation which can explain about political efficacy is "politics is something which is very difficult." A study by Marsh and Grant (1977) in Britain showed that 74 percent of respondents strongly agree or agree while 23 percent strongly disagree or disagree that politics is something that is difficult to understand.

The next statement is "people like me have no right to say the impacts of each of the government." The study of 
Marsh (1975) showed that 14 percent strongly agree, 47 percent agree, 32 percent disagreed and two percent strongly disagree. This finding is similar to studies in Japan, where 61 percent of the respondents felt they had little voice compared to 61 percent in Britain, 66 percent in West Germany and 59 percent in the United States.

According to Kavanagh (1980), the level of competition and political participation in Britain is higher among less-educated voters. In Japan, the efficacy was also associated with less education and in the United States, Flanagan (1978) found that low efficacy is in urban areas than rural areas.

Table 3. Political efficacy based on ethnicity

\begin{tabular}{|c|c|c|c|c|c|c|}
\hline \multirow{2}{*}{ Political Efficacy } & \multirow{2}{*}{ Eth } & \multicolumn{4}{|c|}{ Score (Percentage) } & \multirow{2}{*}{ Total } \\
\hline & & A & L.A & N.S & DnA & \\
\hline \multirow{4}{*}{$\begin{array}{l}\text { Sometimes politics and } \\
\text { government is very difficult for } \\
\text { people like me to understand. }\end{array}$} & \multirow[t]{2}{*}{ M } & \multirow[t]{2}{*}{46.2} & \multirow{2}{*}{19.2} & \multirow[t]{2}{*}{9.6} & \multirow{2}{*}{25.0} & 208 \\
\hline & & & & & & 100 \\
\hline & \multirow{2}{*}{ NM } & \multirow{2}{*}{51.6} & \multirow{2}{*}{20.3} & \multirow{2}{*}{13.5} & \multirow{2}{*}{14.6} & 192 \\
\hline & & & & & & 100 \\
\hline \multirow{4}{*}{$\begin{array}{l}\text { People like me have no right to } \\
\text { say something about what the } \\
\text { government does. }\end{array}$} & \multirow[t]{2}{*}{ M } & \multirow[t]{2}{*}{72.1} & \multirow[t]{2}{*}{17.8} & \multirow[t]{2}{*}{6.3} & \multirow[t]{2}{*}{3.8} & 208 \\
\hline & & & & & & 100 \\
\hline & NM & 521 & $18 ?$ & 135 & 161 & 192 \\
\hline & Nivi & $J 2.1$ & 10.2 & 15.3 & 10.1 & 100 \\
\hline \multirow{4}{*}{$\begin{array}{l}\text { Voting is one way for people like } \\
\text { me to give an opinion on what } \\
\text { the government does }\end{array}$} & \multirow{2}{*}{ M } & \multirow{2}{*}{68.3} & \multirow{2}{*}{7.2} & \multirow{2}{*}{12.5} & \multirow{2}{*}{12.0} & 208 \\
\hline & & & & & & 100 \\
\hline & \multirow{2}{*}{ NM } & \multirow{2}{*}{53.6} & \multirow{2}{*}{20.3} & \multirow{2}{*}{8.9} & \multirow{2}{*}{17.2} & 192 \\
\hline & & & & & & 100 \\
\hline
\end{tabular}

Note: Eth-ethnic, M-Malay, NM-Non Malay

A-Agree, L.A-less agree, N.S-not sure, DnA-do not agree, Tot-total

Based on the three statements above, the percentage of the agree score is higher than the other scores for both the Malays and non-Malays. For the first statement "sometimes politics and government is very difficult for people like me to understand", 46.2 percent of the Malays agree, whereas 51.6 percent of the non-Malays agree. One of the respondents, Mr. Shukor thinks that, "politics is a tool for survival."

Thus, politics is seen as a tool to manipulate the people thereby making it politically difficult to understand. This means that only politicians themselves know what they do. Percentage score of those who agree with the second statement is also high among the Malays at 72.1 percent and 52.1 per cent of non-Malays. The respondents felt that the voice of the people is only heard during elections. Therefore, the opportunity to vote should be used where possible to express the opinion of the people. This view is based on the belief by the respondents that individual voices are not heard by the government unless they are expressed through vote.

Therefore, for the third statement, 68.3 percent of Malays and 53.6 percent of non-Malays agree. Generally, based on the above table, it can be concluded that the respondents are optimistic and still believe that they can make changes for their country. These findings also explain why the number of people who came out to vote for the Parliamentary and State Assemblies is higher in Hulu Langat.

\subsection{Cynical Political Attitudes}

As discussed, cynicism is contrary to efficacy and is associated with a passive attitude. Agger et al. (1961) defines cynicism as "contemptuously distrustful of human nature" and this definition is used to measure personal and political attitudes of a person. Cynicism is then associated with political behavior, such as supporters of Democrats are more cynical than the Republicans. Cynicism will be reduced with an increasing level of 
education, followed by a rise in the level of income. People who have a cynical attitude in politics think that they can not be able to influence a particular issue and therefore their political participation is low. Groups or individuals who have a cynical attitude always think politics is "a dirty business" and therefore politicians can not be trusted.

Table 4. Items in cynical political attitudes based on ethnic

\begin{tabular}{|c|c|c|c|c|c|c|}
\hline \multirow{2}{*}{ Cynical Political Attitudes } & \multirow{2}{*}{ Eth } & \multicolumn{4}{|c|}{ Score (Percentage) } & \multirow{2}{*}{ Total } \\
\hline & & A & L.A & N.S & DnA & \\
\hline \multirow{4}{*}{$\begin{array}{l}\text { Most politicians will promise } \\
\text { something to get votes. }\end{array}$} & \multirow{2}{*}{$\mathrm{M}$} & \multirow{2}{*}{66.8} & \multirow{2}{*}{16.3} & \multirow{2}{*}{12.0} & \multirow{2}{*}{4.8} & 208 \\
\hline & & & & & & 100 \\
\hline & & & & & & 192 \\
\hline & NM & 65.6 & 15.1 & 14.1 & 5.2 & 100 \\
\hline \multirow{4}{*}{$\begin{array}{l}\text { Most politicians are more } \\
\text { concerned with political parties as } \\
\text { compare to the nation. }\end{array}$} & \multirow{2}{*}{ M } & \multirow{2}{*}{69.2} & \multirow{2}{*}{8.7} & \multirow{2}{*}{7.2} & \multirow{2}{*}{14.9} & 208 \\
\hline & & & & & & 100 \\
\hline & NM & 656 & 125 & 80 & 130 & 192 \\
\hline & 1010 & 80.0 & 12.5 & 0.9 & 15.0 & 100 \\
\hline \multirow{4}{*}{$\begin{array}{l}\text { Politicians speak more than they } \\
\text { take action. }\end{array}$} & $\mathrm{M}$ & \multirow{2}{*}{46.6} & 25.0 & \multirow{2}{*}{4.8} & \multirow{2}{*}{23.6} & 208 \\
\hline & & & & & & 100 \\
\hline & TIM & & & & & 192 \\
\hline & NM & 52.6 & 25.0 & 4.2 & 18.2 & 100 \\
\hline \multirow{4}{*}{$\begin{array}{l}\text { When they successfully become } \\
\text { ministers at the helm, they will } \\
\text { never forget the voters. }\end{array}$} & \multirow{2}{*}{$\mathrm{M}$} & \multirow{2}{*}{47.6} & \multirow{2}{*}{15.9} & \multirow{2}{*}{7.7} & \multirow{2}{*}{28.8} & 208 \\
\hline & & & & & & 100 \\
\hline & \multirow{2}{*}{ NM } & \multirow{2}{*}{59.4} & \multirow{2}{*}{7.8} & \multirow{2}{*}{6.3} & \multirow{2}{*}{26.6} & 192 \\
\hline & & & & & & 100 \\
\hline
\end{tabular}

Note: Eth-ethnic, M-Malay, NM-Non Malay

A-Agree, L.A-less agree, N.S-not sure, DnA-do not agree, Tot-total

Generally, based on Table 4, the score for agree is high. This means that cynical political attitudes are also high. Should political efficacy be higher, cynical political attitudes are also low because both are opposing each other. Results showed that the ethnic Malays and non Malays percentage score for agree is high as compared to other scores such as the first statement which percentage of respondents was 66.8 percent Malays and non Malays 65.6 percent. It is also clear that the respondents vote for a political party and not because of leadership. For the third statement, 46.6 percent of the respondents are Malays and 52.6 percent were non-Malays consider "more politicians talk of acting".

Some 47.6 percent ethnic Malays believe that "whenever they become ministers, they will forget the voters". Generally, the four statements reflect that the respondents have high cynical attitudes towards politicians. However, respondents put great faith in the government despite being pessimistic towards politicians. If the leader is same ethnic with the respondents, cynical political attitudes will be low.

For Mrs. Halijah, "I do not think it has anything to do with ethnic. Either Malay or Chinese is just the same. If they win they will forget the voters. You wait for the elections and that is the time they will appear again". This view clearly shows that cynical political attitude is high due to the attitude of the leaders that are not liked by voters. 
This means that cynical politics will not change even if the candidates are from the same ethnicity with the respondents because the most important factor is the attitude of the leader himself and not the ethnic he is representing.

\subsection{Political Trust}

Political trust refers to the confidence and honesty of politicians, trust in the responsiveness of politicians or the confidence that they will hear, pragmatic and can be trusted or the belief that politicians will fulfill their promises and trust in the competency of specific Institutions, especially belief or confidence in the public services (Martin \& Stronach 1992). A study by Martin and Stronach (1992) shows that the people of Japan do not fully believe leaders but the level of trust towards politicians and government leaders in Britain are higher.

The low Political trust in Japan refered to the instability of the ruling government, while in Britain at the end of the 19th century improved standard of living brought about a higher level of political trust. Putnam (2001) also associate social trust with political trust. According to him, social trust refers to trust that others will take into account our interests or at least do not do evil to us. According to Fukuyama (1995), cultural differences also affect social trust.

Thus, Newton (1999) say a very strong social trust is determined by various political parties including the political community, confidence in institutions and trust in politicians. Political trust in this study refers to the belief the people have for their community leaders. Table 5 shows a high percentage score of agree as compared to the other scores.

Some 68.8 percent of Malay respondents agree with the statement "I am satisfied with the current government." Although cynical politics is higher among the respondents due to dissatisfaction with politicians, but on average the respondents still have a political belief or trust in the present government now and believe the present ruling government can bring about development to the country.

Nevertheless, the percentage for scores of do not agree should not be neglected because there are respondents who do not agree with this statement, that is more than 25 percent for Malays and non Malays.

Table 5. Items for ethnic based political trust

\begin{tabular}{|c|c|c|c|c|c|c|}
\hline \multirow{2}{*}{ Political Trust } & \multirow{2}{*}{ Eth } & \multicolumn{4}{|c|}{ Score (Percentage) } & \multirow{2}{*}{ Tota } \\
\hline & & A & L.A & N.S & DnA & \\
\hline \multirow{4}{*}{$\begin{array}{l}\text { I am satisfied with the } \\
\text { government. }\end{array}$} & $\mathrm{M}$ & 68.8 & 26.4 & 1.9 & \multirow{2}{*}{2.9} & 208 \\
\hline & & & & & & 100 \\
\hline & & & & & & 192 \\
\hline & NM & 64.6 & 26.0 & 4.7 & 4.7 & 100 \\
\hline \multirow{4}{*}{$\begin{array}{r}\text { The politicians know what } \\
\text { of this area need }\end{array}$} & \multirow{2}{*}{$\mathrm{M}$} & \multirow{2}{*}{42.3} & \multirow{2}{*}{29.8} & \multirow{2}{*}{13.5} & \multirow{2}{*}{14.4} & 208 \\
\hline & & & & & & 100 \\
\hline & NM & 313 & 214 & 240 & 234 & 192 \\
\hline & & & & & & 100 \\
\hline \multirow{4}{*}{$\begin{array}{r}\text { Whoever holds power v } \\
\text { about changes. }\end{array}$} & \multirow{2}{*}{ M } & \multirow{2}{*}{42.8} & \multirow{2}{*}{31.7} & \multirow{2}{*}{1.4} & \multirow{2}{*}{24.0} & 208 \\
\hline & & & & & & 100 \\
\hline & \multirow{2}{*}{ NM } & \multirow{2}{*}{40.6} & \multirow{2}{*}{27.6} & \multirow{2}{*}{3.6} & \multirow{2}{*}{28.1} & 192 \\
\hline & & & & & & 100 \\
\hline
\end{tabular}

Note: Eth-ethnic, M-Malay, NM-Non Malay

A-Agree, L.A-less agree, N.S-not sure, DnA-do not agree, Tot-total 
For the second statement only 42.3 percent of the Malay respondents agreed with the statement "politicians know what the people of this area of need", while for non-Malays only 31.3 percent. This percentage is not too high as it is less than 50 percent. Nearly 30 percent of Malay respondents do not agree with the statement, while for non-Malays 21.4 percent. For the next statement "whoever holds power will bring about changes", only 42.8 percent Malays agreed, while 31.7 percent did not agree. The non-Malays also recorded a high score for agreeing which is 40.6 percent.

Respondents still have a positive outlook and believe that elected leaders can bring about changes, at least in maintaining the harmony of a multi-ethnic society, in ensuring political and economic stability.

\section{The Impact of New Media on Political Participation}

The development and ascendancy of the Internet as an informational medium, has altered the information environment in which political elites and interested citizens function (Woodly, 2008). We are now experiencing what Schoen (2008) call the "Internet insurgency" approach to political campaigning. This according to Schoen originated with South Korea where the internet is used effectively by politicians. In Malaysia, for example, the internet is used as an alternative to mainstream media which is viewed as being pro-establishment (Ali \& Mohd, 2011).

In the present political scenario, values and attitudes of voters are influenced by the new media, irrespective of ethnicity. As seen in the 2008 Malaysian General Elections, the opposition largely used the new media to make gains resulting in them winning four states and maintaining Kelantan out of the 13 states contested.

Social media have become coordinating tools for political movements (Shirky, 2011). The uprising in the Arab world is an indication of how social media play a crucial role in coordinating protests and bringing people together. In the old days, information technology favoured those in power, because it was one to many. Today's technologies are all many to many, networks in which everyone is connected but no one is in control.

\section{Conclusion}

This study found that values and attitudes do have a relationship with political participation. Other aspects that contribute to political participation are the belief in politics or government and politicians. This sense of trust in turn leads to political participation. From the social perspective, individuals will act on political information which they receive in the form of political participation. The study also found that political participation is not only influenced by external factors but internal factors of the particular individual, such as interest, also encourage political participation. This interest is driven by their social experience through political socialization and the surrounding political situation can sometimes arouse the interest of an individual to participate in politics. Previous studies only take into account the economic and social aspects when discussing political behavior. Considering the elements of values and attitudes, social roles and experience are important criterion. For example, studies by Loh Kok Wah (1997) and Abdul Rahman Embong (1998) look into the way of life and consumerism to describe social and political behavior of middle class in Malaysia. With the advent of the new media and its influence, political participation has taken a new and added dimension. By using the new media to get connected and engage politicians, the attitudes of voters are being affected all over the world. Hence, politicians have to contend with this new development brought about by the new media.

\section{References}

Agger, R. E., Goldstein, M. N., \& Pear, S. A. (1961). Political cynicism: measurement and meaning. Journal of politics, 23, 477-506. http://dx.doi.org/10.2307/2127102

Almond, G. A. (1990). A discipline divided schools and sects in political science. London: Sage Publications.

Conge, P. (1988). The concept of political participation: toward a definition. Comparative politics, 20, 241-248. http://dx.doi.org/10.2307/421669

Deutch, K. W. (1974). Politics and government: How people decide their fate. Boston: Houghton Mifflin.

Embong, A. R. (1998). Social transformation, the state and the middle classes in post-independence Malaysia. In Z. Ibrahim (Ed.), Mediating identities in a changing Malaysian society. London: ASEAN Academic Press.

Esman, M. J. (1973). The management of communal conflict. Public policy, 21, 49-78.

Flanagan, S. C. (1978). The genesis of variant political cultures: contemporary citizen orientations in Japan, Amerika, Britain and Italy. In S. Verba, \& W. Pye (Eds.), The citizen and politics. Stamford: Greylock.

Fukuyama, F. (1995). Trust: the social virtues and the creation of prosperity. London: Hamish Hamilton.

Handelman, H. (2000). The challenge third world development. New Jersey: Prentice Hall. 
Indorf, H. (1979). Malaysia 1978: communal coalitions continue. Asian Survey, 2, 115-123. http://dx.doi.org/10.2307/2643777

Isaak, A. (1975). Politics: an introduction. London: Western Michigan University.

Kavanagh, D. (1980). Political culture in Great Britain: the decline of civic culture. In. G. A. Almond (Ed.), The civic culture revisite (pp. 124-176). Boston: Little Brown.

Marsh, A. (1975). The silent revolution, value priorities and the quality of life in Britain. American political science review, 69, 21-30. http://dx.doi.org/10.2307/1957882

Marsh, A., \& Grant, W. (1977). Tripartism: reality or myth. Government and opposition, 12, 194-211. http://dx.doi.org/10.1111/j.1477-7053.1977.tb00531.x

Martin, C. H., \& Stronach, B. (1992). Politics East and West: A comparison of Japanese and British political culture. New York: M.E Sharpe, Inc.

Milbrath, L. W., \& Goel, M. L. (1977). Political participation: how and why do people get involved in politics? Chicago: Rand McNally.

Mishler, W., \& Clarke, H. D. (1995). Political participation in Canada. In M. S. Whittington, \& G. Williams (Eds.), Canadian politics in the 1990s. Toronto: Nelson.

Newton, K. (1999). Social and political trust. In P. Norris (Ed.), Critical citizens. Oxford: Oxford University Press. http://dx.doi.org/10.1093/0198295685.003.0008

Rodee, C. C., Anderson, T. J., \& Christol, C. Q. (1983). Introduction to political science. New York: McGraw Hill.

Rush, M. (1992). Politics and society: an introduction to political sociology. New York: Prentice Hall.

Salman, A., \& Hasim, M. S. (2011). New Media and Democracy: The Changing Political Landscape in Malaysia. Akademika, 81, 15-21.

Schoen, D. E. (2008). The power of the vote: Electing presidents, overthrowing dictators, and promoting democracy around the world. New York: Harper.

Shirky, C. (2011). The Political Power of Social Media: Technology, the public sphere, and political change. Foreign Affairs, 90(1). Retrieved July 5, 2011, from http://sites.asiasociety.org/womenleaders/wpcontent/uploads/2010/05/ThePolitical-Power-of-Social-MediaForeign Affairs2.pdf

Verba, S., \& Nie, N. H. (1972). Participation in America: political democracy and social equality. New York: Harper \& Row Publishers.

Wah, L. K. (1997). Developmentalism in Malaysia in the 1990s: Is a shift from the politics of ethnicism inderway? Mimeo.

Wasburn, P. C. (1982). Political sociology: approaches concepts hypotheses. New Jersey: Prentice Hall, Inc.

Woodly, D. (2008). New competencies in democratic communication? Blogs, agenda setting and political participation. Public Choice, 134, 109-123. http://dx.doi.org/10.1007/s11127-007-9204-7 